\title{
Fleiss's Kappa: Assessing the Concept of Technology Enabled Active Learning (TEAL)
}

\author{
Nur Farha Hassan ${ }^{1 *}$, Saifullizam Puteh², Amanina Muhamad Sanusi ${ }^{3}$ \\ ${ }^{1,2 \& 3}$ Faculty of Technical and Vocational Education, UniversitiTun Hussein Onn Malaysia, Parit Raja, 86400, Batu \\ Pahat, Johor, MALAYSIA
}

DOI: https://doi.org/10.30880/jtet.2019.11.01.014

Received $28^{\text {th }}$ August 2018; Accepted $19^{\text {th }}$ October 2018; Available online $31^{\text {st }}$ March 2019

\begin{abstract}
Technology Enabled Active Learning (TEAL) is a platform to produce a quality student and improve their academic performance, promotes skills development and increases satisfaction in the learning experience. TEAL also promote marketability skill using technology to become excellent workers in industries. Many researchers have found that concept of TEAL need to be apply in education in order to give chance for student to explore their own studies using technology in a few approach learning (i.e., online, blended, collaborative, practical and interactive learning). Nevertheless, several studies have reported that TEAL is effective approach to make sure student active to join the own activities class to complete their studies. Based on previous findings, five categories of TEAL were identified. This study identifies the important elements of TEAL needs in active learning among assessor's agreement. The aim is to measure the interrater reliability between five (5) assessors of stakeholder in academic fields. This study measures assessor's agreement by using Fleiss's Kappa statistical method. The results show that all assessors agreed with 47 elements in each of construct and 12 elements that do not agree by them. In conclusion, the study recommends the application of TEAL needs in teaching and learning (TnL) process to implement active learning, that more focus on student involve in activity lesson by using technological equipment for generate their knowledge, skill and understanding in their fields. Findings from this study show that all assessors agreed with all of the categories which is suitable for elements of TEAL.
\end{abstract}

Keywords: Technology Enabled Active Learning (TEAL), interrater reliability, Fleiss's Kappa

\section{Introduction}

In the era of globalization, the education sector in this country began to change dynamically to achieve global needs. This has led to various issues related to the understanding of students in the field of study. A better understanding in the field of study lead to the development of a skilled and qualified labour among students at Higher Education Institutions (Chang, Stern, Sondergaard \& Hadgraft, 2009). Technical and Vocational Education Training (TVET) is an institution responsible for developing high-tech graduates in engineering and technology with a variety of technology skills to become professional workers (Bello, Shu'aibu, Saud \& Buntat, 2013). This is the case in today's education which requires the implementation of technology in learning to produce graduates who have the knowledge, understanding and skills to be ready to become a technical manpower that can meet the needs of the industry (Saud, Shu'aibu, Yahaya \& Yasin, 2011).

In fact, TVET also provides a variety of technology curriculum programs to help students be skilled in using digital devices, social media, mobile applications and various electronic devices. This is to increase students' involvement actively in technology innovation learning activities (Aliyu, 2012; Hassan \& Puteh, 2017). Therefore, educational institutions need to play a role in providing a curriculum that meets the market demand for quality and work graduates after graduation (Bridgstock, 2009). This is a key requirement in producing quality graduates to ensure that students 
continue to be trained with a variety of technological and employability skills through effective learning methods (Mouzakitis, 2010; Sanusi \& Puteh, 2017). In conclusion, the effective learning methods concept should be applied in learning to improve academic performance, promotes skills development and increases satisfaction in the learning experience among students.

The effective learning methods using technology ensure students to become a skilled workforce to meet the demands of the economy and the needs of the national market (Bello et al., 2013). However, referring to the quality of university graduates required by industry employers is unable to meet market expectations. Especially in student understanding of the interests of the field involved in developing competent skills. It is important to make students who are knowledgeable in the field of education towards work less in institutional practice (Hanapi, Nordin \& Rus, 2014). This is because of the issues that are often linked to the problem of students not getting a solid understanding of the field (Park \& Choi, 2014; Hassan, 2015). This issue is often discussed in education relating to Teaching and Learning $(\mathrm{TnL})$ sessions that lack the involvement of students in creating an active environment (Pirker, 2013). Even passive TnL processes cannot give students the opportunity to explore their own subjects to form a deep understanding of the areas involved (Che Ahmad et al., 2010).

Thus, creating this active learning can give a new transformation in the development of TnL's environment that is more effective in using technology in terms of pedagogy and content context (Aesaert et al., 2013; Hassan, Puteh \& Buhari, 2015). According to Van Horne, Murniati and Saichaie (2012), expressing a TEAL approach is a method that can be practiced in education that includes a variety of learning that can help improve students' achievement in the field of engagement. Among the helpful approaches to buit a student's understanding is the design of the classroom environment. It needs to emphasize the concept of collaborative learning that involves student discussions to enhance social, active, conceptual and student-centered interactions using technology tools in carrying out TnL activities (Rocca, 2010; Park \& Choi, 2014; Kirkup, 2015).

Additionally, the learning approaches that are often the choice of instructors are online learning which is a learning style that enables students to access information flexibly anytime and anywhere. This allows students to find the information they need to be more prepared before attending classes as well as giving students the opportunity to explore to understand the topics to be learned in the classroom (Stern, 2010). Even today, the combination of learning using technology, the online learning that is used to support face-to-face learning has also been practiced in lectures, which is a blended learning. This approach is to train students to create experience in content and integrated learning activities using technology. Optimal learning outcomes, where students need to get information online but lecturers still have to be responsive to monitor and design the learning materials (Vaughn et al., 2013).

According Noordin dan Sapiee (2010), technical ability and capabilities or better known as practical learning should be applied in each individual to produce skilled manpower in technology integration (Guzey \& Roehrig, 2009). Similarly, interactive learning approaches that use multimedia applications to present a lesson concept or an event visually in linear format to illustrate a dynamic process clearly (Rienties et al., 2013). In this regard, TEAL needs to be implemented in a high-level system of education to help improve student understanding to engage in simulation learning, hands-on and teaching skills using innovative technology tools to build opportunities and experience (Dori \& Belcher, 2005; Hassan, Puteh \& Sanusi, 2018).

Active learning increase understanding of the student to engage in simulated learning, hands on proficiency of students and teaching using the tools of technology innovation for fostering opportunities and experience. Active learning also improved the TnL surrounding with technology device to enhanced understanding of knowledge in fields studies among TVET students to become technologies expert in industries area after graduates. The purpose of this study is to determine the reliability of the elements of TEAL obtained through the consensus of Fliess 's Kappa coefficient of consent value carried out in this study. Thus, this study was conducted to determine the elements of TEAL in education based on the three constructs (Technology Knowledge, Pedagogical Knowledge and Content Knowledge). The elements need in active learning was identified using an agreement rater from assessors after the analysis from the interview session was conducted. Then, an interrater reliability was used to obtain the final elements of TEAL. The interrater reliability analysis is important to interpret experience or interest from different assessors to have congruent hypothesis in finding elements of research (Cohen, Manion \& Morrison, 2011). Fliess's Kappa coefficient was used to analysis the agreement of assessors. This study is to create an active environment in TnL that involves students and effectively in order to develop the skills of workability with the use of technology to become quality graduates. 


\section{Research Methodology}

Based on previous studies, researchers have identified the elements of TEAL that can help improve students' understanding and knowledge of the fields involved to better meet the needs of the industry. The purpose of this study is to measure the assessor's agreement on the five categories of learning that can help determine the elements required in the TEAL format consisting of three constructs per section. This active learning approach is implement to make sure student will be more interest to join discussion in class lesson for increase the communicate with their friends and lecture in actively. To develop an active environment in $\mathrm{TnL}$, lecture and students need to do more creative and innovative activity by using technology devices for helping them learn more about their field's studies to make fun and joyful.

Therefore, to verify the elements of TEAL that have been explored the next step that needs to be done is to analyse the value of the coefficient using Fleiss's Kappa calculation method. This step is to look at the reliability of the findings of the elements obtained in this study. The assessors involved in this research are comprised of five assessors involved in the field of academic development with stakeholders. Therefore, the selection of assessors in this study is as follows:

- have experience of teaching and serving more than five years and above,

- have knowledge of the academic curriculum at the university level,

- have a Master or PhD in engineering and technology to meet the needs of the study.

Fleiss's Kappa analysis is the method of calculating the percentage of consent to obtaining interrater reliability index (Cohen, 1960; Fleiss, 1981). Calculation formula of Fleiss's kappa used to determine the confidence index ( $\kappa)$ is as shown in Figure 1.

$$
\mathbf{K f}=\frac{P a-P s}{1-P s}
$$

$\mathrm{Pa} \quad=$ The stage of approval of the subordinate based on the observation

Ps = The number of probable hypothesis of consent, using the observation data to calculate the probability of random observations at each level

Fig. 1 - Fleiss's kappa Calculation

According Viera and Garrett (2005), if the value $\kappa$ approaches value 1 , this means that the assessor reaches agreement among the assessors. Whereas if the value $\kappa$ approached 0 , it means no agreement between the assessor. Based on Table 1 shows the scale value of the Kappa coefficient of consent i.e. $\kappa$ value to see the value of reliability as stated by Landis and Koch (1977).

Table 1 - The value of the Kappa coefficient approvals.

\begin{tabular}{cc}
\hline Kappa Value $(\kappa)$ & Level of Agreement \\
\hline$<0.00$ & Poor \\
$0.01-0.20$ & Slight \\
$0.21-0.40$ & Fair \\
$0.41-0.60$ & Moderate \\
$0.61-0.80$ & Substantial \\
$0.81-1.00$ & Almost Perfect \\
\hline
\end{tabular}

The significance of measuring reliability of the elements of TEAL using Fleiss's Kappa is better estimate analysis tool to control for that random agreement factor that might be expected from different assessors (Bajpai, Bajpai \& Chaturvedi, 2015). This method is possible to recommended when researcher have ordinal or nominal scale data. In this study have nominal scale that categorical range 0 or $1(0$ is not agree and 1 is agree). In this study, the interrater reliability test is involved to finalize theme finding from the selection of assessors.

\section{Findings and Discussions}

The results obtained from this study are based on measuring the consent of the assessors on five categories comprising three constructs to acquire the elements of TEAL needed to enhance the students' understanding and knowledge. Based on previous studies, researchers have acquired the necessary elements of TEAL for each category for each construct.

For the first category, online learning is a teaching method that can help build students' social and interpersonal skills in learning information through the internet and sharing information in partnership online. This can indirectly improve the quality and skills of self-employed in learning the skills of graduates. Referring to the results of the approval of five assessors, the findings from the analysis of each element of online learning based on constructs; technology knowledge, pedagogical knowledge and content knowledge are briefly described in Table 2 . 
Table 2 - Summary of findings on assessors' consent for online learning elements.

\begin{tabular}{|c|c|c|c|c|c|c|c|}
\hline \multicolumn{8}{|c|}{ Categories: Online Learning } \\
\hline \multirow{2}{*}{ Construct } & \multirow{2}{*}{ Elements } & \multicolumn{5}{|c|}{ Raters } & \multirow{2}{*}{$\%$ Agreement } \\
\hline & & $\mathbf{A}$ & B & $\mathbf{C}$ & D & $\mathbf{E}$ & \\
\hline \multirow{6}{*}{$\begin{array}{l}\text { Technological } \\
\text { knowledge }\end{array}$} & Computer Technology & 1 & 1 & 1 & 1 & 0 & 0.80 \\
\hline & Internet & 1 & 1 & 1 & 1 & 1 & 1.00 \\
\hline & Telecommunication Media & 1 & 1 & 1 & 1 & 1 & 1.00 \\
\hline & Web Application & 1 & 1 & 1 & 1 & 1 & 1.00 \\
\hline & Internet of Things (IOT) & 1 & 0 & 1 & 0 & 1 & 0.60 \\
\hline & Software & 0 & 1 & 1 & 0 & 0 & 0.40 \\
\hline \multirow{4}{*}{$\begin{array}{l}\text { Pedagogical } \\
\text { knowledge }\end{array}$} & Web based learning & 0 & 1 & 1 & 1 & 1 & 0.80 \\
\hline & Social Interaction & 1 & 1 & 0 & 1 & 0 & 0.60 \\
\hline & MOOCs Learning & 1 & 1 & 1 & 0 & 0 & 0.60 \\
\hline & Sharing Information & 0 & 0 & 1 & 0 & 0 & 0.20 \\
\hline \multirow{5}{*}{$\begin{array}{c}\text { Content } \\
\text { knowledge }\end{array}$} & Explore activities & 0 & 1 & 0 & 1 & 0 & 0.40 \\
\hline & Problem solving & 1 & 1 & 1 & 1 & 0 & 0.80 \\
\hline & Flexibility in Access Information & 0 & 1 & 1 & 1 & 1 & 0.80 \\
\hline & Cooperative learning & 0 & 0 & 1 & 0 & 0 & 0.20 \\
\hline & Discussion Group Forum & 1 & 1 & 1 & 1 & 0 & 0.80 \\
\hline
\end{tabular}

Table 2 shows that there are two elements that have no consensus between the assessors as showing the value of $\kappa$ approaching the value of 0 ie software for technological knowledge; sharing information for pedagogical knowledge and; exlplore activities and cooperative learning for content knowledge. The rest of the elements are showing the value of $\kappa$ approaching the value of 1 which means the assessor reaches the consent of the assessors. This result was supported by Friedman and Friedman (2013), where students able to enhance their knowledge in class when they used varieties of technology. However, there are other research said that students just need to choose the suitable technology to support their learning, rather than used variety of technologies (He, 2013; Kizilcec \& Halawa, 2015).

While in the second category, this blended learning is a teaching method that can help build organizational skills and face-to-face learning management using online technology. Referring to the results of the approval of five assessors, the findings from the analysis of each element of blended learning based on the construcs; technology knowledge, pedagogical knowledge and content knowledge are as in Table 3.

Table 3 - Summarized of findings of assessors' approval for blended learning elements.

\begin{tabular}{|c|c|c|c|c|c|c|c|}
\hline \multicolumn{8}{|c|}{ Categories: Blended Learning } \\
\hline \multirow[t]{2}{*}{ Construct } & \multirow[t]{2}{*}{ Elements } & \multicolumn{5}{|c|}{ Raters } & $\%$ \\
\hline & & $\mathbf{A}$ & $\mathbf{B}$ & $\mathbf{C}$ & D & $\mathbf{E}$ & Agreement \\
\hline \multirow{3}{*}{$\begin{array}{l}\text { Technological } \\
\text { knowledge }\end{array}$} & Online Conference & 1 & 1 & 1 & 1 & 0 & 0.80 \\
\hline & Social Media / Virtual Technology & 1 & 1 & 1 & 0 & 0 & 0.60 \\
\hline & $\begin{array}{l}\text { Electronic Technology (Clicker } \\
\text { Personal Response System) }\end{array}$ & 1 & 1 & 1 & 1 & 0 & 0.80 \\
\hline \multirow[t]{4}{*}{$\begin{array}{l}\text { Pedagogical } \\
\text { knowledge }\end{array}$} & $\begin{array}{l}\text { Flexibility Learning (Online And } \\
\text { Face To Face) }\end{array}$ & 0 & 1 & 1 & 1 & 1 & 0.80 \\
\hline & Mini-Lecture & 1 & 1 & 1 & 0 & 1 & 0.80 \\
\hline & Project Based Learning (POBL) & 0 & 1 & 0 & 1 & 1 & 0.60 \\
\hline & Video sharing & 1 & 0 & 0 & 0 & 0 & 0.20 \\
\hline \multirow{2}{*}{$\begin{array}{c}\text { Content } \\
\text { knowledge }\end{array}$} & Presentation Skills & 0 & 1 & 1 & 1 & 1 & 0.80 \\
\hline & Creativity and innovative & 0 & 1 & 0 & 1 & 1 & 0.60 \\
\hline
\end{tabular}

Table 3 shows that there is an element that has no consensus among the assessors because it shows the value of $\kappa$ approaches the value of 0 ie video sharing for pedagogical knowledge. The rest of the elements are showing the value of $\kappa$ approaching the value of 1 which means the assessor reaches the consent of the assessors. This finding in line with the result from Henrie et al., (2015) where they stated that blended learning need to be apply in learning process to make sure students will engaged in class activity. Findings from Zacharis (2015), Okaz (2015) and Elson and Cheng 
(2016) also showed that the multivariate elements in learning helps student to get involved in classroom activities, especially by using social media technologies.

Next, the third category was collaborative learning which was a teaching method that can build communication skills by sharing opinions and collaborating in one team. Referring to the results of five assessors approvals, the findings from the analysis of each collaborative learning element based on constructs; technology knowledge, pedagogical knowledge and content knowledge are briefly described in Table 4.

Table 4 - Summarized findings of assessors approval for collaborative learning elements.

\begin{tabular}{clccccccc}
\hline & \multicolumn{1}{c}{ Categories : Collaborative Learning } \\
\hline \multirow{2}{*}{ Construct } & \multicolumn{1}{c}{ Elements } & Raters & & \% Agreement \\
Technological & Desktop technology workspace & 0 & 1 & 0 & 1 & 1 & 0.60 \\
knowledge & Electronic Media & 1 & 0 & 1 & 1 & 1 & 0.80 \\
& Telecommunication & 0 & 0 & 1 & 0 & 0 & 0.20 \\
& Internet of Things ( IOT ) & 1 & 0 & 1 & 0 & 0 & 0.40 \\
Pedagogical & Social Interaction and communication & 1 & 1 & 1 & 1 & 1 & 1.00 \\
knowledge & Instructions Tutor and Friend & 1 & 1 & 0 & 1 & 1 & 0.80 \\
Content & Accountability of Individual and Group & 1 & 1 & 0 & 1 & 1 & 0.80 \\
& Decision Making and Action & 0 & 1 & 0 & 1 & 1 & 0.60 \\
& Critics Thinking & 0 & 1 & 1 & 1 & 1 & 0.80 \\
& Presentation and Exploration of & 1 & 1 & 1 & 1 & 1 & 1.00 \\
\hline
\end{tabular}

Table 4 shows that there are two elements that have no consensus between the assessors because it shows the value of $\kappa$ approaches value 0 namely telecommunications and Internet of Thing (IOT) for technology knowledge. The rest of the elements are showing the value of $\kappa$ approaching the value of 1 which means the assessor reaches the consent of the assessors. The results showed that the social interaction and communication is the higher elements. The results in line with the statement from Claros, Cobos and Collazos (2016), that state that students can improve their self-esteem by learning to communicate and share their own opinions in group discussion. In addition, Vliet, Winnips and Brouwer (2015) also stated that student's metacognitive can be enhance using the knowledge in their own contents. They can also make a good decision and gain a good result in their group work.

For the fourth category, practical learning is a teaching method that can help build the technical skills of students using technology equipment or machines. This can create hands-ons for students to develop the experience of handling technological equipment in helping to produce products, projects and jobs. Referring to the results of the approval of five assessors, the findings from the analysis of each element of practical learning based on construcs; technology knowledge, pedagogical knowledge and content knowledge are in Table 5.

Table 5 - Summary findings of assessors' approval from practical learning elements.

\begin{tabular}{|c|c|c|c|c|c|c|c|}
\hline \multicolumn{8}{|c|}{ Categories: Practical Learning } \\
\hline \multirow{2}{*}{ Construct } & \multirow[b]{2}{*}{ Elements } & \multicolumn{5}{|c|}{ Raters } & \multirow{2}{*}{$\%$ Agreement } \\
\hline & & $\mathbf{A}$ & B & $\mathbf{C}$ & D & $\mathbf{E}$ & \\
\hline \multirow{3}{*}{$\begin{array}{l}\text { Technological } \\
\text { knowledge }\end{array}$} & Scientific Tools & 1 & 1 & 1 & 1 & 1 & 1.00 \\
\hline & Hands on Tools and Machinery & 1 & 1 & 1 & 1 & 1 & 1.00 \\
\hline & Stimulation Video & 0 & 0 & 1 & 0 & 0 & 0.20 \\
\hline \multirow{3}{*}{$\begin{array}{l}\text { Pedagogical } \\
\text { knowledge }\end{array}$} & $\begin{array}{l}\text { Practical Projects, Products and } \\
\text { Solutions Based on Procedural } \\
\text { Learning }\end{array}$ & 0 & 1 & 1 & 1 & 1 & 0.80 \\
\hline & Experience Learning & 1 & 1 & 0 & 1 & 1 & 0.80 \\
\hline & Group Activities & 0 & 1 & 1 & 1 & 1 & 0.80 \\
\hline \multirow{3}{*}{$\begin{array}{c}\text { Content } \\
\text { knowledge }\end{array}$} & $\begin{array}{l}\text { Hands on Experimental / Controlling } \\
\text { Devices }\end{array}$ & 1 & 1 & 1 & 1 & 1 & 1.00 \\
\hline & Actual Experiment & 1 & 1 & 1 & 1 & 1 & 1.00 \\
\hline & $\begin{array}{l}\text { Scientific Skills and Analysis } \\
\text { Technical }\end{array}$ & 1 & 1 & 1 & 1 & 1 & 1.00 \\
\hline
\end{tabular}

Table

shows there 
element that has no agreement between the assessors as it shows the value of $\kappa$ approaches the value of 0 ie simulation video for technology knowledge. The rest of the elements are showing the value of $\kappa$ approaching the value of 1 which means the assessor reaches the consent of the assessors. The finding showed that the process of developing a practical learning also need technologies to achieve the goals in learning, especially in improving student's hands-on skills such as handle machines, tools or programming software which will enhanced their technical skills (Duis et al., 2013). According to Nikolic (2014), the practical learning also gives students an opportunity to use technologies for gaining experience in scientific tools, results analysis, conducting experiments and find a solution to get actual finding.

In addition, in the fifth category, interactive learning is a teaching method that helps to develop creative and critical cognitive skills in using multimedia software. Referring to the results of the five assessors' approvals, the findings of the analysis of each interactive learning element based on constructs; technology knowledge, pedagogical knowledge and content knowledge are given in Table 6.

Table 6 - Summarized findings of assessor's approval for interactive learning elements

\begin{tabular}{|c|c|c|c|c|c|c|c|}
\hline \multicolumn{8}{|c|}{ Categories : Interactive Learning } \\
\hline \multirow[t]{2}{*}{ Construct } & \multirow[t]{2}{*}{ Elements } & \multicolumn{5}{|c|}{ Raters } & \multirow{2}{*}{$\begin{array}{c}\% \\
\text { Agreement }\end{array}$} \\
\hline & & $\mathbf{A}$ & B & $\mathbf{C}$ & D & $\mathbf{E}$ & \\
\hline \multirow{6}{*}{$\begin{array}{l}\text { Technological } \\
\text { knowledge }\end{array}$} & Multimedia Technology & 1 & 1 & 1 & 1 & 0 & 0.80 \\
\hline & Presentation Software & 1 & 1 & 1 & 1 & 1 & 1.00 \\
\hline & Video Digital Tools & 1 & 1 & 0 & 1 & 0 & 0.80 \\
\hline & Web Application & 1 & 1 & 0 & 0 & 0 & 0.40 \\
\hline & Programming Software & 1 & 1 & 0 & 1 & 1 & 0.80 \\
\hline & Web-based software & 0 & 1 & 1 & 0 & 1 & 0.60 \\
\hline \multirow{4}{*}{$\begin{array}{l}\text { Pedagogical } \\
\text { knowledge }\end{array}$} & Animation Demonstration & 0 & 1 & 1 & 1 & 1 & 0.80 \\
\hline & Graphic, Audio and Video Design & 1 & 1 & 1 & 1 & 1 & 1.00 \\
\hline & Game Based Learning & 0 & 1 & 1 & 1 & 1 & 0.80 \\
\hline & $\begin{array}{l}\text { Group Work by Discussion and } \\
\text { Sharing }\end{array}$ & 1 & 0 & 0 & 0 & 0 & 0.20 \\
\hline \multirow{4}{*}{$\begin{array}{l}\text { Content } \\
\text { knowledge }\end{array}$} & Imagination and Illustrate & 0 & 1 & 0 & 1 & 1 & 0.80 \\
\hline & $\begin{array}{l}\text { High Productivity /Higher Order } \\
\text { Thinking Skills (HOTS) }\end{array}$ & 0 & 1 & 1 & 1 & 0 & 0.60 \\
\hline & High Performance & 1 & 1 & 1 & 1 & 0 & 0.80 \\
\hline & Decision Making & 0 & 0 & 0 & 0 & 1 & 0.20 \\
\hline
\end{tabular}

Table 6 shows that there are three elements that have no consensus among the assessors because the value $\kappa$ approaches value 0 . The element is a web application for technology knowledge; group work by discussion and sharing of pedagogical knowledge and; decision making for content knowledge. The remaining elements show the value of $\kappa$ approaching the value of 1 which means the assessor reaches the consent of the assessors. Hence, the result showed that the presentation software and graphic, audio and video design is the most important elements. The results in line with Chen et al., (2015), which stated that learning through interactive video helped students to understand more in class, especially by using visual or games animation. As a result, students will be improved in their learning performance and motor skills when they used multimedia technology in their learning methods (Hsiao \& Chen, 2016). Overall, there were five categories was identified in determining the elements of TEAL among students. Table 7 shows a summary of the overall findings of the Kappa coefficient of scale approvals for each category involved from the study conducted.

Researchers obtain the findings of the five assessors to acknowledge and agree on the elements acquired based on constructs; technology knowledge, pedagogy and content for each of the elements of TEAL obtained. Overall it is a good level of agreement. Based on Table 7, the researcher obtained a coefficient of 0.870 on the element of practical learning that is a almost perfect scale. While the value of coefficients for online learning, blended learning, collaborative learning and interactive learning has a substantial consensus scale. This shows that every element required for each category is to help students become more active with the more effective TnL process. These are to enhance understanding of areas involved in building self-employed skills to become quality students. That is in line with Van Horne et al., (2012), promoting active learning in education will enhanced a quality student which can developed their own knowledge and skills. The finding was also supported by Sun and Chiang (2014) that stated that by using multivariate approach of technologies, it will help students to understand more about what they had learn and encourage students to involve actively in learning process. 
Table 7 - Fleiss's Kappa coefficient value index for the entire category.

\begin{tabular}{clccccc}
\hline No & \multicolumn{1}{c}{ Categories } & \multicolumn{2}{c}{$\begin{array}{c}\text { Consensus of } \\
\text { Assessors }\end{array}$} & $\begin{array}{c}\text { Interrater } \\
\text { reliability } \\
\text { (\%) }\end{array}$ & $\begin{array}{c}\text { Value } \\
\text { Fleiss's } \\
\text { Kappa }\end{array}$ & $\begin{array}{c}\text { Level of } \\
\text { Agreement }\end{array}$ \\
\hline & & Yes & No & & & \\
1. & Online learning & 11 & 4 & 66.67 & 0.722 & Substantial \\
2. & Blended learning & 8 & 1 & 66.67 & 0.722 & Substantial \\
3. & Collaborative learning & 8 & 2 & 70.00 & 0.750 & Substantial \\
4. & Practical learning & 8 & 1 & 84.44 & 0.870 & Almost Perfect \\
5. & Interactive learning & 11 & 3 & 65.00 & 0.708 & Substantial \\
\hline
\end{tabular}

This study discusses about the elements of TEAL that have agreement from assessor to help increase the understanding of the students in the field of endeavour to form a workability skill to become quality graduates. In the opinion of assessor, all the suitable elements that specified in this research should be involved in development of TEAL for creating more effective learning. The agreement of assessor is the platform to make student more comfortable with active environment by using technology to gain ideas, skills, and confident level in create their own understanding about the fields of studies. That will give students had opportunity to explore actively more about the subjects in deeply for help their technology knowledge, pedagogical knowledge and content knowledge (Morrison \& Phillip, 2009; Davoudi, \& Ajoun, 2013).

This means that students themselves need to understand of the learning approach used in the classroom to enhance their experience, achievement and skills through a more dynamic and efficient learning environment space using technology during lectures. Indirectly, this TEAL approach has a positive impact in the production activities to implement active learning strategies more focused on learning outcomes and not on technology tools only, to enhance the involvement of students in the teaching and learning $(\mathrm{TnL})$ process more effectively.

\section{Conclusion}

The Fleiss's kappa method was selected because according to Cohen (1960) and Fleiss (1981), the construction of items that would refer to the elements obtained from the study should be revised through the value of Fleiss's kappa coefficients in determining the reliability of the elements obtained. Fleiss's kappa is a continuation of Cohen Kappa (to measure approval between two or more assessors). Based on McHugh (2012) which states Fleiss's kappa is a simple measurement of approvals between assessors using percentage value. This is important to ensure that the overall elements of TEAL by category are appropriate to the purpose of the study. This study involves the agreement of assessor involved in the implement of curriculum and academics in Malaysian Technical University (MTUN). Comprises five experts representing energy instructors as well as practitioners in technologists to provide more technology tools in create active learning environment. This is to attract students to engage directly in learning activities during lectures. Based on the agreement of five assessor regarding elements of TEAL, the next process to be implemented construction of the questionnaire instrument to measure the suitability of categories and construct in this study. This is to support the decision of the consensus assessor in determining the effective elements TEAL for students apply it. The findings show that the reliability of assessors for each category measured is needed in forming these TEALs in HEIs to help improve the students' understanding and knowledge in the field to develop skills to work with technology to become quality students from various aspects. The implication of the findings is to implement the active learning activities to increasing the involvement of students in teaching and learning $(\mathrm{TnL})$. Therefore, the findings are to support the direction in the field of TVET towards TEAL approach to build skilful and quality of graduates. Where students have the opportunity to undergo more active learning activities by using technology in explore and understand topic related to subjects in more depth. Expert approvals to apply of TEAL approach in learning to assist students in generate knowledge in technology, pedagogy and content.

\section{Acknowledgments}

The author would like to thank to Malaysian Ministry of Higher Education (MOHE), Universiti Tun Hussein Onn Malaysia (UTHM) and office for Research, Innovation, Commercialization and Consultancy Management (ORICC) for supporting this research under the grant PPG Research Grant vote No: V011. 


\section{References}

Chang, R. L., Stern, L., Sondergaard, H., \& Hadgraft, R. (2009). Places for learning engineering: A preliminary report on informal learning spaces. In Proceedings of the Research in Engineering Education Symposium, Palm Cove, QLD. Retrieved December, 12, 2009.

Bello, H., Shu'aibu, B., Saud, M.S., \& Buntat, Y., (2013). ICT Skills for Technical and Vocational Education Graduates' Employability. World Applied Sciences Journal, 23(2). 204-207. ISSN 1818-4952. IDOSI Publications, 2013. DOI: 10.5829/idosi.wasj.2013.23.02.588.

Hanapi, Z., Nordin, M. S., \& Rus, R. C. (2014). Unemployment Problem among Graduates of Technical Field: Competencies of the Graduates and Quality of the Education. Sains Humanika, 2(2).

Park, E. L., \& Choi, B. K. (2014). Transformation of classroom spaces: traditional versus active learning classroom in colleges. Higher Education, 68(5), 749-771.

Hassan, N. F. (2015). Pemahaman pelajar melalui aplikasi TEAL (technology enabled active learning) dalam pembelajaran amali (Doctoral dissertation, Universiti Tun Hussein Onn Malaysia).

Che' Ahmad, C.N., Osman, K. \& Halim, L. (2010). Physical And Psychosocial Aspect S Of Science Laboratory Learning Environment. Procedia Social And Behavioral Sciences Journal, 9: 87-91.

Saud,M.S., Shu'aibu, B., Yahaya. N., \& Yasin, M.A.M., (2011). Effective Integration of Information and Communication Technologies (ICTs) in Technical And Vocational Education and Training (TVET) Toward Knowledge Management in The Changing World of Work. African Journal of Business Management,5(16). 66686673.

Aliyu, M.B., (2012). Integrating e-Learning in Technical and Vocational Education: A Technical Review. International Journal of Academic Research in Business and Social Sciences May 2012, 2(5). ISSN: 2222-6990.

Hassan, N. F., \& Puteh, S. (2017). A Survey of Technology Enabled Active Learning in Teaching and Learning Practices to Enhance the Quality of Engineering Students. Advanced Science Letters, 23(2), 1104-1108.

Bridgstock, R. (2009). The graduate attributes we've overlooked: Enhancing graduate employability through career management skills. Higher Education Research \& Development, 28(1), 31-44.

Mouzakitis, G., (2010). The Role Of Vocational Education And Training Curricula In Economic Development. Procedia Social and Behavioral Sciences, 2(4). 3914-3920.

Sanusi, A. M., \& Puteh, S. (2017). An approach of excellence talent in engineering education programmed of enhancing the quality of students. Advanced Science Letters, 23(2), 1109-1112.

Pirker, J., Riffnaller Schiefer, M., Tomes, L. M., \& Gutl, C. (2016). Motivational Active Learning in Blended and Virtual Learning Scenarios: Engaging Students in Digital Learning. Handbook of Research on Engaging Digital Natives in Higher Education Settings, 416.

Stern, J., (2010). Introduction to Online Teaching and Learning, Laureate Education. Inc. Marina del Rey, CA.

Aesaert, K. et al. (2013). The content of educational technology curricula: a cross-curricular state of the art. Educational Technology Research and Development, 61(2), 131-151.

Hassan, N. F., Puteh, S., \& Buhari, R. (2015). Student understanding through the application of technology enabled Active Learning in practical training. Procedia-Social and Behavioral Sciences, 204, 318-325.

Van Horne, S., Murniati, C.,\& Saichaie, K. (2012). Assessing Teaching and Learning in Technology-Infused TILE Classrooms at the University of Iowa. in EDUCAUSE Learning Initiative's Seeking Evidence of Impact.

Rocca, K. A. (2010). Student participation in the college classroom: An extended multidisciplinary literature review. Communication Education, 59(2), 185-213.

Kirkup, L. (2015). Inquiry-oriented learning. Learning and Teaching Academic Standards project (LTAS). Australian Learning and teaching fellows. University of technology Sydney. GEDC, Adelaide, Dec. 2015.

Vaughan, N. D., Cleveland. I.M., \& Garrison, D. R. (2013). Teaching in Blended Learning Environments: Creating and Sustaining Communitiesof Inquiry. Athabasca, AB: Athabasca University Press.

Noordin, S., \& Sapiee, F., (2010). Tahap Pencapaian Pengetahuan Pedagogi dan Kandungan Dalam Kalangan Bakal Guru Fizik. Repositori Universiti Teknologi Malaysia. 
Guzey, S. S., \& Roehrig, G. H.(2009). Teaching science with technology: Case Studies Of Science Teachers' Development of Technology, Pedagogy, and Content Knowledge. Contemporary Issues in Technology and Teacher Education, 9(1). 25-45.

Rienties, B., Brouwer, N., \& Lygo, B.S., (2013). The Effects of Online Professional Development on Higher Education Teachers' Beliefs and Intentions Towards Learning Facilitation and Technology. Teaching and Teacher Education, 29. $122-131$

Dori, Y. J., \& Belcher, J. (2005). How does technology-enabled active learning affect undergraduate students' understanding of electromagnetism concepts?. The journal of the learning sciences, 14(2), 243-279.

Hassan, N. F., Puteh, S., \& Sanusi, A. (2018). Elements of Technology Enabled/Enhanced Active Learning (TEAL) to Enhance Quality and Employability of Bachelor's Students. In MATEC Web of Conferences (150): p. 05005. EDP Sciences.

Viera, A. J. \& Garrett, J. M. (2005). Understanding Inter observer Agreement: The Kappa Statistic. Fam Med 37(5): 360-363.

Landis, J. R., \& Koch, G. G. (1977). The measurement of observer agreement for categorical data. Biometrics, 159174.

Bajpai S., Bajpai R.C. \& Chaturvedi H. K. (2015). Evaluation of Inter-Rater Agreement and Inter-Rater Reliability for Observational Data: An Overview of Concepts and Methods. Journal of the Indian Academy of Applied Psychology, 41(3), 20-27.

Friedman, L. W., \& Friedman, H. H. (2013). Using social media technologies to enhance online learning. Journal of Educators Online, 10(1), n1.

He, W. (2013). Examining students' online interaction in a live video streaming environment using data mining and text mining. Computers in Human Behavior, 29(1), 90-102.

Kizilcec, R. F., \& Halawa, S. (2015). Attrition and achievement gaps in online learning. In Proceedings of the Second (2015) ACM Conference on Learning@ Scale (pp. 57-66). ACM.

Henrie, C. R., Bodily, R., Manwaring, K. C., \& Graham, C. R. (2015). Exploring intensive longitudinal measures of student engagement in blended learning. The International Review of Research in Open and Distributed Learning, $16(3)$

Zacharis, N. Z. (2015). A multivariate approach to predicting student outcomes in web-enabled blended learning courses. The Internet and Higher Education, 27, 44-53.

Okaz, A. A. (2015). Integrating blended learning in higher education. Procedia-Social and Behavioral Sciences, 186, 600-603

Elson. S \& Annie Y. N. Cheng (2016). Towards a framework of interactions in a blended synchronous learning environment: what effects are there on students' social presence experience. Interactive Learning Environments, 24:3, 487-503, DOI: 10.1080/10494820.2014.881391.

Claros, I., Cobos, R., \& Collazos, C. A. (2016). An approach based on social network analysis applied to a collaborative learning experience. IEEE Transactions on Learning Technologies, 9(2), 190-195.

Van Vliet, E. A., Winnips, J. C., \& Brouwer, N. (2015). Flipped-class pedagogy enhances student metacognition and collaborative-learning strategies in higher education but effect does not persist. CBE-Life Sciences Education, 14(3), $\operatorname{ar} 26$.

Duis, J. M., Schafer, L. L., Nussbaum, S., \& Stewart, J. J. (2013). A process for developing introductory science laboratory learning goals to enhance student learning and instructional alignment. Journal of Chemical Education, 90(9), 1144-1150.

Nikolic.S, (2014). Training laboratory: Using online resources to enhance the laboratory learning experience. In IEEE International Conference on Teaching, Assessment and Learning for Engineering: Learning for the Future Now (TALE 2014), 2014, pp. 51-54.

Chen, M., Hao, Y., Li, Y., Wu, D., \& Huang, D. (2015, June). LIVES: Learning through interactive video and emotionaware system. In Proceedings of the 16th ACM International Symposium on Mobile Ad Hoc Networking and Computing (pp. 399-400). ACM.

Hsiao, H. S., \& Chen, J. C. (2016). Using a gesture interactive game-based learning approach to improve preschool children's learning performance and motor skills. Computers \& Education, 95, 151-162. 
Van Horne, S., Murniati, C., Gaffney, J. D. H., \& Jesse, M. (2012). Case Study: Promoting Active Learning in Technology-Infused TILE Classrooms at the University of Iowa. Journal of Learning Spaces, 1(2), 1-10.

Sun, M., \& Chiang, F.-K. (2014). Active Learning Spaces New Directions for Teaching and Learning. Educational Technology \& Society, 18(2), 394-396. Retrieved from http://public.eblib.com/EBLPublic/ PublicView. do?ptiID $=1662688$.

Morrison, J.L., \& Phillip, L., (2009). Technology Enhanced Active Learning in the Electrical Engineering and Computer Science Department at MIT. The International HETL Review, 1(5).

Davoudi, N., \& Ajoun, R. (2013). Pedagogy centered on Learner in E , M and P-Learning Continuum : Active and Situated Learning. International Journal of Information and Education Technology, 3(3). https://doi. org/10.7763/IJIET.2013. V3.297

Cohen, J. (1960). A coefficient of agreement for nominal scales. Educational and psychological measurement, 20(1), $37-46$.

Fleiss, J.L. (1981). Statistical methods for rates and proportions (2nd ed.). New York: Wiley

M. McHugh, (2012). Interrater reliability: the kappa statistic. Biochemical medical, vol. 22, no. 3, pp. 276-282, 2012. 